\title{
Front Matter: Volume 6754
}

, "Front Matter: Volume 6754," Proc. SPIE 6754, Geoinformatics 2007: Geospatial Information Technology and Applications, 675401 (6 September 2007); doi: 10.1117/12.768549

SPIE. Event: Geoinformatics 2007, 2007, Nanjing, China 


\title{
PROCEEDINGS OF SPIE
}

\section{Geoinformatics 2007 \\ Geospatial Information Technology and Applications}

\author{
Peng Gong \\ Yongxue Liu \\ Editors
}

\section{5-27 May 2007 \\ Nanjing, China}

Organized by

Nanjing University (China)

Sponsored by

Nanjing University (China)

CPGIS-The International Association of Chinese Professionals in Geographic Information Sciences

Cartography Committee, AAG (USA)

GIS Committee, AAG (USA)

Cartography and GIS Committee, The Geographical Society of China (China)

Cartography and GIS Committee, Chinese Society for Geodesy, Photogrammetry

and Cartography (China)

\section{Cosponsored by}

State Key Laboratory of Remote Sensing Science, Jointly Sponsored by the Institute of Remote Sensing Applications of Chinese Academy of Sciences and Beijing Normal University (China) Jiangsu Provincial Bureau of Surveying and Mapping (China)

Published by

SPIE

Volume 6754 
The papers included in this volume were part of the technical conference cited on the cover and title page. Papers were selected and subject to review by the editors and conference program committee. Some conference presentations may not be available for publication. The papers published in these proceedings reflect the work and thoughts of the authors and are published herein as submitted. The publisher is not responsible for the validity of the information or for any outcomes resulting from reliance thereon.

Please use the following format to cite material from this book:

Author(s), "Title of Paper," in Geoinformatics 2007: Geospatial Information Technology and Applications, edited by Peng Gong, Yongxue Liu, Proceedings of SPIE Vol. 6754 (SPIE, Bellingham, WA, 2007) Article CID Number.

ISSN 0277-786X

ISBN 9780819469144

Published by

SPIE

P.O. Box 10, Bellingham, Washington $98227-0010$ USA

Telephone +1 3606763290 (Pacific Time) · Fax +1 3606471445

SPIE.org

Copyright (c) 2007, Society of Photo-Optical Instrumentation Engineers

Copying of material in this book for internal or personal use, or for the internal or personal use of specific clients, beyond the fair use provisions granted by the U.S. Copyright Law is authorized by SPIE subject to payment of copying fees. The Transactional Reporting Service base fee for this volume is $\$ 18.00$ per article (or portion thereof), which should be paid directly to the Copyright Clearance Center (CCC), 222 Rosewood Drive, Danvers, MA 01923. Payment may also be made electronically through CCC Online at copyright.com. Other copying for republication, resale, advertising or promotion, or any form of systematic or multiple reproduction of any material in this book is prohibited except with permission in writing from the publisher. The CCC fee code is $0277-786 \mathrm{X} / 07 / \$ 18.00$.

Printed in the United States of America.

Publication of record for individual papers is online in the SPIE Digital Library.

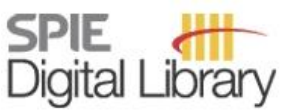

SPIEDigitalLibrary.org

Paper Numbering: Proceedings of SPIE follow an e-First publication model, with papers published first online and then in print and on CD-ROM. Papers are published as they are submitted and meet publication criteria. A unique, consistent, permanent citation identifier (CID) number is assigned to each article at the time of the first publication. Utilization of CIDs allows articles to be fully citable as soon they are published online, and connects the same identifier to all online, print, and electronic versions of the publication. SPIE uses a six-digit CID article numbering system in which:

- The first four digits correspond to the SPIE volume number.

- The last two digits indicate publication order within the volume using a Base 36 numbering system employing both numerals and letters. These two-number sets start with $00,01,02,03,04,05$, $06,07,08,09,0 \mathrm{~A}, 0 \mathrm{~B} \ldots \mathrm{OZ}$, followed by 10-1Z, 20-2Z, etc.

The CID number appears on each page of the manuscript. The complete citation is used on the first page, and an abbreviated version on subsequent pages. Numbers in the index correspond to the last two digits of the six-digit CID number. 


\section{Contents}

\section{Part One}

$\begin{array}{ll}\text { xV } & \text { Conference Committees } \\ \text { xix } & \text { Introduction }\end{array}$

\section{SESSION 1 GIS FOR ENVIRONMENT AND HEALTH}

675402 Assisting video surveillance in micro-spatial environments with a GIS approach [6754-01] X. Li, East China Normal Univ. (China); X. Zhang, Univ. of Memphis (USA); L. Tan, Nanjing Univ. (China)

675403 GIS-based earthquake hazard assessment of urban power systems: Memphis electric substations [6754-02]

X. Zhang, Univ. of Memphis (USA); Y. Li, China Geological Survey (China); X. Li, East China Normal Univ. (China); Y. Liu, FedEx Express (USA); T. LU, Nanjing Univ. (China)

675404 Study on GIS-based building of S-57 data models [6754-03]

Y. Li, Sun Yat-sen Univ. (China) and South China Agricultural Univ. (China); S. Bao, South China Agricultural Univ. (China); P. Zhou, J. Tan, Guangzhou Institute of Geochemistry (China); S. Chen, Guangzhou Institute of Geochemistry (China) and French Naval Academy Research Institute (France)

675405 Study on a new global data structure STQIE-based [6754-04]

L. Guan, C. Cheng, S. Guo, G. Pu, M. Sun, Peking Univ. (China)

675406 The geo-ontology based on stratified rough sets [6754-05]

W. Cui, Wuhan Univ. of Technology (China); Y. Yao, Shanghai Maritime Univ. (China); Y. Yu, Wuhan Univ. of Technology (China); D. Li, State Key Lab. of Information Engineering in Surveying, Mapping and Remote Sensing (China)

675407 An efficient distributed shortest path algorithm based on hierarchically structured topographical model [6754-06]

W. Guo, X. Zhu, Y. Liu, Wuhan Univ. (China)

675408 A new global GIS architecture based on STQIE model [6754-07]

C. Cheng, L. Guan, S. Guo, G. Pu, M. Sun, Peking Univ. (China)

675409 Improving method of line (area) buffer creating model used in Maplnfo [6754-08] R. C. Peng, Y. Chen, G. H. Liu, L. X. Guo, Y. D. Zheng, H. R. Chen, Dalian Naval Academy (China)

6754 OA Integration of spatial information technology for digital urban planning [6754-09] A. Dang, H. Shi, X. He, Y. Li, Tsinghua Univ. (China) 
6754 OB Study on lateral buffer generation in GIS [6754-10]

J. Wang, Y. Rui, J. Liu, D. Shen, Nanjing Univ. (China)

6754 OC Research on the diathesis, knowledge structure and education scheme of GIS personnel [6754-11]

M. Li, W. Dai, Y. Zhao, Nanjing Univ. (China)

6754 OD Fuzzy description model for indeterminate direction relation [6754-12]

J. He, Y. Liu, Wuhan Univ. (China) and Ministry of Education Key Lab. of Geographic Information System (China); Y. Yu, Wuhan Univ. (China)

$6754 \mathrm{OE}$ Research of the relationship between space accessiblity and urban land price by pointbased space syntax [6754-13]

K. Song, M. Li, Y. Shao, Y. Liu, Nanjing Univ. (China)

6754 OF Knowledge-based geographic model integration [6754-14]

H. Yang, G. LU, J. Wang, Y. Hu, Y. Yang, Y. Wen, Nanjing Normal Univ. (China)

6754 OG Research on GIS open service solution based on Parlay API architecture [6754-15]

X. Zhu, M. Li, Nanjing Univ. (China)

$6754 \mathrm{OH}$ Data organization appproach to spatio-temporal GIS in campus real estate [6754-16]

Y. Zhang, X. Feng, S. Zhao, P. Xiao, X. Le, Nanjing Univ. (China)

$6754 \mathrm{Ol}$ The study of spatio-temporal reasoning model and application in the digital tobacco [6754-17]

J. Luo, W. Cui, Institute of Remote Sensing Applications (China)

6754 0J Role-based access control model for GIS [6754-18]

Y. Pan, Nanjing Normal Univ. (China) and Jiangsu Univ. (China); Y. Sheng, J. Zhou, Nanjing Normal Univ. (China)

6754 OK Effects of cell sizes on resistance surfaces in GIS-based cost distance modeling for landscape analyses [6754-19]

W. Liu, D. Chen, N. A. Scott, Queen's Univ. (Canada)

$6754 \mathrm{OL}$ Improved algorithm for data conversion from raster to vector [6754-20]

J. Teng, State Oceanic Administration (China); F. Wang, Northern Illinois Univ. (USA)

6754 OM Assessment of micro-regional internal accessibility based on road network [6754-21]

T. Nie, M. Li, Z. Jiang, K. Huang, Nanjing Univ. (China)

6754 ON Study on the complex network characteristics of urban road system based on GIS [6754-22]

Z. Gao, Z. Chen, Y. Liu, K. Huang, Nanjing Univ. (China)

675400 Research on the Yin-Yang structure of the main city of Nanjing by the method of GIS [6754-23]

W. Yuan, X. Zhu, B. Zhao, Nanjing Univ. (China) 
$6754 \mathrm{OP}$ Improving the performance of spatial raster analysis in GIS using GPU [6754-24]

Y. WU, Y. Ge, Hohai Univ. (China); W. Yan, Nanjing Univ. of Technology (China); X. Li, Hohai Univ. (China)

$6754 \mathrm{OQ}$ Research and implementation of road monitoring GIS system [6754-25]

J. YU, J. WU, M. Yi, East China Normal Univ. (China)

6754 OR A study on service-based multi-agent geospatial data sharing method [6754-26]

L. Teng, N. Liu, R. Liu, Zhejiang Univ. (China) and Zhejiang Provincial Key Lab. of Geographic Information System (China); L. Lu, Taizhou Municipal Land Administrative Bureau (China)

6754 OS Research on assessing conditions of establishing industrial land and spatial integration for region along Yangtze of Changzhou aided by GIS [6754-27]

D. Sun, W. Liu, Wuxi Land Resource Bureau (China); R. Jiang, ShenZhen Real Estate Research Ctr. (China)

6754 OT Integration and utilization of the historical cultural resources of Nanjing based on cluster analysis [6754-28]

J. XU, Y. Zong, Nanjing Univ. (China)

6754 OU Quick location determination based on geographic keywords of natural language [6754-29]

D. Guo, W. Cui, Institute of Remote Sensing Applications (China)

$6754 \mathrm{OV}$ Analysis on the spatial structure and characteristics of the eminent tourism resources in south Jiangsu based on GIS [6754-30]

Y. Wang, J. Zhang, J. Ran, Nanjing Univ. (China)

6754 OW Analysis on evolution process of the Meizizhou reach of the Yangtze River from the revetment based on GIS [6754-31]

G. QU, J. Wang, S. Bai, Nanjing Normal Univ. (China); G. Cao, Nanjing Normal Univ. (China) and Linyi Normal Univ. (China)

6754 OX Study on growth monitoring of winter wheat based on change vector analysis [6754-32]

X. GU, Y. Pan, L. Han, C. Xu, Beijing Normal Univ. (China)

6754 OY A GIS-based approach for comparative analysis of potential fire risk assessment [6754-33] Y. Sun, L. Hu, H. Liu, Beijing Normal Univ. (China)

$67540 Z$ Study on drought fine distribution over rugged terrains based on GIS [6754-34]

Y. H. Gao, Chongqing Institute of Meteorological Science (China); Y. Z. Tian, Southwest Normal Univ. (China); Z. J. Chen, Y. H. Tang, Chongqing Institute of Meteorological Science (China)

675410 Divisions of urban economic effect regions based on revised potential model: a case study of Jiangsu Province since 1978 [6754-35]

J. Zhu, W. Guan, J. Xu, X. Chen, Nanjing Univ. (China) 
675411 The study on dynamic cadastral coding rules based on kinship relationship [6754-36] H. Xu, N. Liu, R. Liu, Zhejiang Univ. (China); J. Lu, Taizhou Municipal Land Administrative Bureau (China)

675412 The study on the spatio-temporal model of the moving objects based on LBS [6754-37] L. Zhou, D. Zhang, X. He, Huaihai Institute of Technology (China)

675413 Theory of ontology and land use ontology construction [6754-38]

G. Zhou, Y. Liu, J. Chao, C. Shen, H. Yang, Nanjing Univ. (China)

675414 Qualitative spatial reasoning for direction relation [6754-39]

P. Chen, East China Institute of Technology (China) and Central South Univ. (China); J. Wu, Shandong Jiaotong Univ. (China); D. Li, East China Institute of Technology (China); X. Liu, Central South Univ. (China)

675415 Research on the new route choice method of main optical cables based on Dijkstra algorithm: a case study of Guanyun County [6754-40]

M. Zhang, Nanjing Univ. (China); X. Gu, Nanjing Univ. of Posts and Telecommunications (China); Z. Chen, X. Li, M. Su, Nanjing Univ. (China)

675416 GIS based quantification method of spatial competition [6754-41]

Z. Chen, M. Li, H. Fu, D. Chen, Nanjing Univ. (China)

675417 Processing model of multi-scale geospatial data based on genetic algorithms [6754-42] H. Deng, F. WU, Q. Zhao, D. Dong, Information Engineering Univ. (China)

675418 Bidirectional Dijkstra algorithm for best-routing of urban traffic network [6754-43]

L. Chen, J. Zhou, J. Li, Y. Chen, Beijing Normal Univ. (China)

675419 Study on the balance of datum land prices among cities based on city gravitation model and stochastic diffuson equation [6754-44]

Y. Liu, Y. Liu, Y. Xia, W. Liu, Z. Lan, Wuhan Univ. (China)

\section{SESSION 2 WEBGIS, VIRTUAL GIS, GRID GIS, AND MOBILE GIS}

6754 1A Station-based water vapor estimation using sparse national GPS network [6754-45]

Y. Gao, W. Tao, Y. Zhang, Univ. of Calgary (Canada)

6754 1B GIS and agent based spatial-temporal simulation modeling for assessing tourism social carrying capacity: a study on Mount Emei scenic area, China [6754-46]

R. Zhang, Chongaing Institute of Technology (China)

6754 1C A study on spatial decision support systems for HIV/AIDS prevention based on COM GIS technology [6754-47]

K. Yang, H. Luo, S. Peng, Q. Xu, Yunnan Normal Univ. (China)

6754 ID A photogrammetric method for monitoring sandbank movement [6754-48]

Z. Deng, Nanjing Univ. (China) and BasicEngineering Co., Ltd. (Japan); S. Takao,

BasicEngineering Co., Ltd. (Japan) 
6754 1E Architecture for service-oriented WebGIS in the mode of multilevel-multilayer organizing [6754-49]

F. Li, M. Li, J. Liang, Nanjing Univ. (China)

6754 IF A study on the wetland dynamics and its main driving factors in Sanjiang plain, Northeast China [6754-50]

G. Li, Lanzhou Univ. (China) and Jilin Normal Univ. (China); K. Song, Northeast Institute of Geography and Agricultural Ecology (China); S. Niu, Lanzhou Univ. (China)

6754 1G The mine information system based on digital strata and its preliminary application [6754-51]

J. Hu, H. Zhu, X. Li, C. Wang, Tongji Univ. (China)

$6754 \mathrm{1H} \quad$ Monitoring variation of water turbidity and related environmental factors in Poyang Lake National Nature Reserve, China [6754-52]

W. Liu, Y. Liu, Wuhan Univ. (China); C. M. Mannaerts, International Institute for GeoInformation Science and Earth Observation (Netherlands); G. Wu, Wuhan Univ. (China) and International Institute for Geo-Information Science and Earth Observation (Netherlands)

$675411 \quad$ Research on the flood prevention and control system of the Poyang lake area based on WebGIS [6754-53]

X. Liu, Y. Chen, Q. Sun, Jiangxi Univ. of Science and Technology (China)

$67541 \mathrm{~J}$ Impact of floating population on the epidemic of tuberculosis: a spatial analysis [6754-54] Z. Jia, Beijing Univ. of Posts and Telecommunications (China) and Beijing Institute of Microbiology and Epidemiology (China); X. He, Beijing Research Institute for TB Control (China); W. Zhao, Beijing Institute of Microbiology and Epidemiology (China); Y. An, Beijing Research Institute for TB Control (China); W. Cao, Beijing Institute of Microbiology and Epidemiology (China); X. Li, Institute of Remote Sensing Applications (China)

$67541 \mathrm{~K}$ Assessment of the regional landslide susceptiblity based on GIS [6754-55]

Z. Sun, Jilin Normal Univ. (China); S. Xie, Nanjing Urban Planning Bureau (China); K. Zhang, China Univ. of Geosciences (China); X. Zheng, Jilin Normal Univ. (China); Y. Zhu, China Univ. of Geosciences (China)

$67541 \mathrm{~L} \quad$ Study of the quantitative evaluation of the visual satisfaction of environmental space of urban sculpture based on relationship between human and environment: taking three environmental spaces of urban sculpture in Nanjing as an example [6754-56]

Z. Jiang, Nanjing Univ. (China); N. Wang, Nanjing Univ. of Technology (China); Q. Qi, C. Qin, Nanjing Univ. (China)

$67541 \mathrm{M}$ A GIS-based landslide hazard assessment by multiple regression analysis [6754-57] X. Pan, Cold and Arid Regions Environmental and Engineering Research Institute (China) and Tokyo Univ. of Agriculture and Technology (Japan); H. Nakamura, Tokyo Univ. of Agriculture and Technology (Japan); N. Tamotsu, CNK Geotechnical Institute Inc. (Japan); Z. Nan, Cold and Arid Regions Environmental and Engineering Research Institute (China) 
6754 iN Research about the location technologies of forest fire detecting based on GIS [6754-58] A. Zhang, Institute of Geographical Sciences and Natural Resources Research (China) and Graduate School of the Chinese Academy of Sciences (China); Q. Qi, Institute of Geographical Sciences and Natural Resources Research (China); L. Jiang, C. Guo, Institute of Geographical Sciences and Natural Resources Research (China) and Graduate School of the Chinese Academy of Sciences (China)

675410 Research on scenario simulation of land-use planning based on CA model: A case study in Kunming metropolitan area [6754-59]

$X$. Li, Y. Liu, X. Fu, Nanjing Univ. (China)

$6754 \mathrm{lP}$ Terrain matching image pre-process and its format transform in autonomous underwater navigation [6754-60]

X. Cao, F. Zhang, Peking Univ. (China); D. Yang, Beihang Univ. (China); B. Yang, Peking Univ. (China)

6754 1Q An ArcHydro-feature based data model of water resources system of irrigation district in northwest China [6754-61]

S. Yi, Z. Chang, L. Li, Huazhong Univ. of Science and Technology (China)

6754 IR A mathematical model for flood loss estimation based on spatial grid [6754-62]

Q. Zhu, X. Chen, Peking Univ. (China); H. Yang, China Institute of Water Resources and Hydropower Research (China); Z. Huang, Peking Univ. (China)

6754 is Research on dynamical mechanism of land desertification [6754-63]

M. Yang, Wuhan Univ. (China); R. Guo, Wuhan Univ. (China) and Bureau of Resources and Housing Management of ShenZhen Municipality (China); Q. Li, Wuhan Univ. (China); P. Luo, Bureau of Resources and Housing Management of ShenZhen Municipality (China)

6754 IT Application of two hydrological models to Weihe River basin: a comparison of VIC-3L and SWAT [6754-64]

H. Hu, Lanzhou Univ. (China); G. Wang, Lanzhou Univ. (China) and Institute of Mountain Hazards and Environment (China); X. Bi, Nanjing Univ. (China); F. Yang, C. E., Lanzhou Univ. (China)

\section{Part Two}

SESSION 3 GIS THEORY, ALGORITHM, AND APPLICATION

$67541 \mathrm{U}$ An architecture for ontology-based geographic information semantic grid service [6754-65]

Q. Zhan, D. Li, Z. Shao, Wuhan Univ. (China)

6754 IV Mobile agent based online integration modeling for traffic information services [6754-66] Q. Li, D. Gao, Z. Fang, L. Li, Wuhan Univ. (China)

6754 IW NDF: an effective mobile GIS physical storage model [6754-67]

K. Li, Institute of Geographical Sciences and Natural Resources Research (China) and Graduate School of the Chinese Academy of Sciences (China); E. Zhong, G. Song, G. Cao, L. Zhang, Institute of Geographical Sciences and Natural Resources Research (China); Q. Wu, Beijing Landview Mapping Information Technology Co., Ltd. (China) 
$67541 \mathrm{X} \quad$ Building web-based spatial information solution around open specifications and open source software: a case study of web-based demographic information system of Changzhou [6754-68]

Z. Jiang, M. Li, B. Zhao, T. Nie, Nanjing Univ. (China)

6754 1Y SQL level global query resolving for web based GIS [6754-69]

B. Chen, F. Huang, Z. Huang, Peking Univ. (China); Y. Sun, Peking Univ. (China) and Shijiazhuang Institute of Railway Technology (China); Y. Fang, Peking Univ. (China)

$67541 \mathrm{Z}$ Monte Carlo ray tracing algorithm for rendering virtual geographical environment [6754-70] J. Ma, S. Xu, G. Gu, P. Jia, Nanjing Univ. (China)

675420 P2P based efficient on-line spatial images delivery [6754-71]

Y. Liu, J. Gong, H. Wu, Wuhan Univ. (China)

$675421 \quad$ DIY-style GIS service in mobile navigation system integrated with web and wireless GIS [6754-72]

Y. Yan, J. Wu, C. Fan, M. Wang, S. Dai, East China Normal Univ. (China)

675422 Using GeoRSS feeds to distribute house renting and selling information based on Google map [6754-73]

Y. Nong, K. Wang, Wuhan Univ. (China); L. Miao, South China Agricultural Univ. (China);

F. Chen, Wuhan Univ. (China)

675423 Integration agent-based models and GIS as a virtual urban dynamic laboratory [6754-74]

P. Chen, Tongji Univ. (China) and Key Lab. of Geographic Information Science (China);

M. Liu, Tongji Univ. (China)

675424 Data penetration transmission in P2P [6754-75]

S. Zheng, X. Feng, Nanjing Univ. (China)

675425 Designing and implementing outdoor augmented reality system based on ARToolKit [6754-76]

Z. He, Y. Liu, Wuhan Univ. (China); Y. Chang, Shandong Normal Univ. (China); S. Hu, Guangdong Land Resource Information Ctr. (China)

675426 Study on architecture and implementation of adaptive spatial information service [6754-77] Z. Yu, Y. Wang, B. Luo, Institute of Geographical Sciences and Natural Resources Research (China)

675427 Large-scale P2P network based distributed virtual geographic environment (DVGE) [6754-78]

X. Tan, L. Yu, F. Bian, Wuhan Univ. (China)

675428 Using GeoRSS to syndicate the spatiotemporal information [6754-79]

B. Zhao, M. Li, Z. Jiang, Nanjing Univ. (China)

675429 Global grid systems for geospatial information: status and thinking [6754-80] J. Ben, Information Engineering Univ. (China) and State Key Lab. of Resource and Environmental Information System (China); X. Tong, S. Ji, Information Engineering Univ. (China) 
6754 2A Constructing 3D GIS mine model and its visualization [6754-81]

H. Chen, Nanjing Univ. (China) and Nanjing Forestry Univ. (China); H. Fu, F. Li, Nanjing Univ. (China)

6754 2B A new methodology to mobile green spatial information service grid based on mobile agent [6754-82]

G. Tian, Henan Polytechnic Univ. (China), Liaoning Technical Univ. (China), and Tongji Univ. (China); M. Liu, X. Tong, Tongji Univ. (China)

6754 2C Spatial information multi-grid for service [6754-83]

Z. Shao, C. Zhong, M. Li, X. Wang, Wuhan Univ. (China)

6754 2D Embedded GIS based on the convergenced network [6754-84]

Z. Chen, Graduate Univ. of Chinese Academy of Sciences (China) and Institute of Geographic Sciences and Natural Resources Research (China); Q. Qi, Institute of Geographic Sciences and Natural Resources Research (China)

$67542 \mathrm{E}$ Research on the middleware of grid GIS: distributed cooperative computing GIS software and its key technologies [6754-85]

Y. Sun, Peking Univ. (China) and Shijiazhuang Institute of Railway Technology (China);

Y. Fang, B. Chen, Peking Univ. (China); T. A. Rana, Yasar Univ. (Turkey)

$67542 \mathrm{~F}$ Application based on ArcObject inquiry and Google maps demonstration to real estate database [6754-86]

J. Hwang, National Taipei Univ. (Taiwan)

$67542 \mathrm{G}$ Web-GIS based information management system to Bureau of Law Enforcement for Urban Management [6754-87]

H. Sun, C. Wang, B. Ren, Huazhong Univ. of Science and Technology (China)

$67542 \mathrm{H} \quad$ Research on ecological function zoning information system based on WebGIS [6754-88]

J. Zhang, Henan Polytechnic Univ. (China); G. Zhang, Jiaozuo Junior Specialized

Postsecondary Normal Colleges (China)

675421 Research on three-dimensional visualization based on virtual reality and Internet [6754-89] Z. Wang, Zhengzhou Univ. (China); H. Yang, Zhengzhou Univ. (China) and China Institute of Water Resources and Hydropower Research (China); H. Zhao, Zhengzhou Univ. (China); J. Li, China Institute of Water Resources and Hydropower Research (China); Q. Zhu, Peking Univ. (China); X. Zhang, China Institute of Water Resources and Hydropower Research (China); K. Sun, Zhengzhou Univ. (China)

$67542 \mathrm{~J}$ Application of virtual reality GIS in urban planning: an example in Huangdao district [6754-90]

Y. Han, Information Ctr. of Qingdao Geotechnical Investigation and Surveying Research Institute (China) and Ocean Univ. of China (China); X. Qiao, W. Sun, L. Zhang, Information Ctr. of Qingdao Geotechnical Investigation and Surveying Research Institute (China)

6754 2K WebGIS application based on real-time traffic flow network analysis [6754-91]

S. Jiao, Beijing Vocational and Technical Institute of Industry (China); Y. Qu, Z. Liu, Q. Feng, J. Ren, X. Chen, Beijing Normal Univ. (China) 
$67542 \mathrm{~L}$ The application of speech technology in mobile GIS [6754-92]

L. Zhang, Y. Long, C. Qian, L. Hu, G. LV, Nanjing Normal Univ. (China) and MOE Key Lab. of Virtual Geographical Environment (China)

$67542 \mathrm{M}$ The applications of geo-referenced data visualization technologies for GIS [6754-93] J. Liu, J. Wang, Y. Zhou, Nanjing Univ. (China)

$67542 \mathrm{~N}$ Construction of urban land demand model base system based on web services [6754-94] K. Huang, M. Li, Z. Gao, T. Nie, Nanjing Univ. (China)

675420 GIS web service interaction model based on REST [6754-95] G. Wang, F. Bian, Wuhan Univ. (China)

6754 2P A new VideoGIS: integration of WebGIS with streaming media technology based on Internet [6754-96]

J. Wang, Nanjing Univ. of Technology (China)

$67542 Q \quad$ A Jini-based dynamic service WebGIS model [6754-97]

W. Xuan, X. Chen, Z. Huang, Peking Univ. (China); G. Zhao, Wuhan Univ. (China)

$67542 R \quad$ Information system building of the urban electromagnetic environment [6754-98]

J. Wang, Y. Rui, D. Shen, Q. Yu, Nanjing Univ. (China)

675425 Research on integration of web electronic map and 3D virtual scene in network environment [6754-99]

Q. Wang, J. Yang, G. Zheng, X. Huang, China Univ. of Geosciences (China)

\section{SESSION 4 SPATIAL DECISION SUPPORT SYSTEM AND GOVERNMENT GIS}

$67542 \mathrm{~T}$ GIS-based integrated assessment and decision support system for land use planning in consideration of carbon sequestration benefits [6754-100]

J. Wang, J. M. Chen, M. Li, W. Ju, Nanjing Univ. (China)

$67542 \mathrm{U}$ Spatial distribution analysis of residential living space features in Shanghai based on spatial accessibility calculations: a method study [6754-101]

Y. Qi, J. G. Xu, G. R. Zhang, B. G. Liao, Nanjing Univ. (China)

$67542 \mathrm{~V}$ Design and implementation on information construction of county level land and resources departments [6754-102]

W. Liu, D. Sun, New District Substation of Wuxi Land and Resources Bureau (China)

67542 W Research on optimum location of urban land based on CA [6754-103]

G. Wu, C. Song, B. Wei, Q. Wu, H. Si, Nanjing Univ. (China)

$67542 X \quad$ Research on designing ontologies for location-based services [6754-104]

G. Cheng, Q. Du, Z. Cai, Wuhan Univ. (China); M. Huang, Jiangxi Finance \& Economics Univ. (China); H. Zhao, Wuhan Univ. (China) and Jiangxi Normal Univ. (China)

$67542 Y \quad$ A cooperated P2P GIS for loose coupled governmental application [6754-105]

C. Li, K. Xie, X. Ma, C. Cai, Y. Sun, Peking Univ. (China) 
675422 Defining a certain range of land consolidation with support of GIS and visualization technology [6754-106]

M. Jia, M. Li, H. Fu, T. Wang, F. Li, Nanjing Univ. (China)

675430 The social problems and strategies of the government GIS in China [6754-107]

N. Chen, Z. Fu, Wuhan Univ. (China)

675431 Scenario planning based on geomatics: a case study in Zijin mountain national forest park [6754-108]

M. Li, Y. He, G. Xu, W. Wu, Nanjing Forestry Univ. (China); B. Wang, Nanjing Univ. (China)

675432 The discussion of crucial techniques in the emergency solution of special equipment security systems [6754-109]

Z. Li, R. Liu, N. Liu, Zhejiang Univ. (China)

675433 Study on informatization framework of urban pipelines [6754-110]

R. Tian, Q. Zhu, W. Zhong, H. Gao, Ningbo Planning \& Geography Information Ctr. (China)

675434 Application of real-time cooperative editing in urban planning management system [6754-111]

C. Jing, R. Liu, N. Liu, Zhejiang Univ. (China); W. Bao, The Jinhua City Planning Administrative Bureau (China)

675435 The spatial decision-supporting system combination of RBR \& CBR based on artificial neural network and association rules [6754-112]

Y. Tian, F. Bian, Wuhan Univ. (China)

675436 Distributed decision-support GIS application based on web-service [6754-113]

L. Yu, X. Tan, Wuhan Univ. (China); J. Huang, The Land and Resources Information Ctr. of GuangDong Province (China)

675437 Architecture design of the national plant treasure management information system based on GIS: a case study of Gugong Date Garden in Hebei province [6754-1 14]

S. Shen, R. Li, D. Shen, C. Tong, X. Fu, Hebei Normal Univ. (China)

675438 An overview of the methods of GIS-based land-use suitability analysis [6754-115] J. Yang, Y. Liu, S. Wang, Nanjing Univ. (China)

675439 Research on comprehensive evaluation to land consolidation supported by GIS: a case study of Shaoshan city in Hunan province [6754-116]

S. Wang, M. Li, M. Su, Nanjing Univ. (China)

6754 3A Study on disparity of regional economic development based on geoinformatic Tupu and GWR model: a case of growth of GDP per capita in China from 1999 to 2003 [6754-117] F. Li, M. Li, J. Liang, Nanjing Univ. (China)

6754 3B Testing the spatial distribution of economic activity in Jiangsu province by means of spatial association methods [6754-118]

Y. Ge, W. Wang, S. Zhang, Hohai Univ. (China); W. Yan, Nanjing Univ. of Technology (China) 
6754 3C Land reclamation information system of mining area based on GIS [6754-119]

Q. Chen, Henan Polytechnic Univ. (China) and China Univ. of Mining and Technology

(China); Z. Hu, China Univ. of Mining and Technology (China); C. Liu, J. GU, Y. Wang, Henan

Polytechnic Univ. (China)

6754 3D Application of GIS in foreign direct investment decision support system [6754-120] J. Zhou, Huazhong Univ. of Science and Technology (China); K. Sun, Nanjing Institute of Technology (China)

6754 3E Application GIS on university planning: building a spatial database aided spatial decision [6754-121]

L. Miao, X. Wu, South China Agricultural Univ. (China); K. Wang, Y. Nong, Wuhan Univ. (China)

6754 3F Design and realization of spatial information service system for government administration of natural disaster [6754-122]

L. Wang, J. Liu, Y. Zhu, L. Shi, Chinese Academy of Surveying and Mapping (China)

$67543 \mathrm{G}$ A design of strategic alliance based on value chain of surveying and mapping enterprises in China [6754-123]

H. Duan, X. Huang, Wuhan Univ. (China)

$67543 \mathrm{H} \quad$ Research on the model of land resource optimal allocation based on land use niche [6754-124]

Y. Yu, Wuhan Univ. of Technology (China); J. He, Wuhan Univ. (China) and Ministry of Education Key Lab. of Geographic Information System (China)

675431 Investigation on the development of three-dimensional city models in decision making in urban design [6754-125]

X. Zhang, Tsinghua Univ. (China); D. L. Cao, Orient Digital Express Network Co., Ltd. (China)

6754 3J A spatial cluster method for prime farmland selection [6754-126]

X. Zheng, China Univ. of Geosciences (China); W. Xiang, Univ. of North Carolina at Charlotte (USA); J. Dong, Shandong Normal Univ. (China); B. Zhong, Nanjing Univ. (China)

$67543 \mathrm{~K}$ A route planning algorithm for the shortest distance based on the division road network [6754-127]

J. Zhang, China Univ. of Mining and Technology (China); L. Li, National Geomatics Ctr. of China (China); L. Zhang, NavInfo Co., Ltd. (China); Y. Chen, China Univ. of Mining and Technology (China)

$67543 \mathrm{~L} \quad$ Government information resource catalog and its service system realization [6754-128] S. Gui, L. Li, H. Wang, Wuhan Univ. (China); Z. Peng, Shenzhen Information Ctr. for Urban Planning and Land Management (China)

$67543 \mathrm{M}$ The approach for shortest paths in fire succor based on component GIS technology [6754-129]

J. Han, Hohai Univ. (China); Y. Zhao, Nanjing Municipal Bureau of State Land and Resources (China); K. W. Dai, Nanjing Normal Univ. (China) 
6754 3N An object-oriented model-base system frame [6754-130]

L. Zhang, Institute of Remote Sensing Applications (China) and Graduate Univ. of Chinese Academy of Sciences (China); Y. Liu, Institute of Remote Sensing Applications (China);

Z. Zhang, Nanjing Univ. (China); S. Yan, Institute of Remote Sensing Applications (China)

675430 Optimal allocation model of construction land based on two-level system optimization theory [6754-131]

M. Liu, Y. Liu, Wuhan Univ. (China); Y. Xia, South Digital Technology Co., Ltd. (China); Q. Lei, Wuhan Univ. (China)

Author Index 


\title{
Conference Committees
}

\author{
Honorary Chairs
}

Shupeng Chen, Senior Academician, Institute of Geographical Science and Resources Research, Chinese Academy of Sciences (China)

Guanhua Xu, Academician, Chinese Academy of Science; Ministry of Science and Technology (China)

International Steering Committee

Michael F. Goodchild, University of California at Santa Barbara (USA)

Michael Batty, University College London (United Kingdom)

John R. Townshend, University of Maryland College Park (USA)

Arthur Cracknell, University of Dundee (United Kingdom)

Robert MacMaster, University of Minnesota (USA)

Harvey Miller, University of Utah (USA)

Kate Beard, University of Maine (USA)

Philip Howarth, University of Waterloo (Canada)

Deren Li, Wuhan University (China)

Jun Gao, Information Engineering University of the People's Liberation Army (China)

Qingxi Tong, Institute of Remote Sensing Application, Chinese Academy of Sciences (China)

Jiayao Wang, Information Engineering University of the People's Liberation Army (China)

Xiaowen Li, Beijing Normal University; Institute of Remote Sensing Application, Chinese Academy of Sciences (China)

Gar-on Yeh, University of Hong Kong (China)

Jiyuan Liu, Institute of Geographical Science and Resources Research, Chinese Academy of Sciences (China)

Yanying Xu, State Bureau of Surveying and Mapping (China)

Jun Chen, National Center for Fundamental Geographic Information (China)

Guocheng Zhang, National Remote Sensing Center (China)

Yimin Jin, National Remote Sensing Center (China)

Lizhong Yu, East China Normal University (China)

Peijun Shi, Beijing Normal University (China)

Ke Liao, Institute of Geographical Science and Resources Research, Chinese Academy of Sciences (China)

Jicheng Cheng, Beijing University (China)

Xingyuan Huang, Nanjing University (China)

Ershun Zhong, Institute of Geographical Science and Resources Research, Chinese Academy of Sciences (China) 
Conference Chair

Jingming Chen, Academician, Royal Society of Canada (Canada) International Institute for Earth System Science, Nanjing University (China)

Technical Committee

Bing Xu, Chair, University of Utah (USA)

Manchun Li, Chair, Nanjing University (China)

Members

Axing Zhu, University of Wisconsin, Madison (USA)

Anrong Dang, Tsinghua University (China)

Bin Li, Central Michigan University (USA)

Chenghu Zhou, Institute of Geographical Science and Resources Research, Chinese Academy of Sciences (China)

Cynthia A. Brewer, Penn State University (USA)

Fahui Wang, Northern Illinois University (USA)

Fang Qiu, University of Texas, Dallas (USA)

Guonian Lu, Nanjing Normal University (China)

Guoqing Sun, University of Maryland, College Park (USA)

Hui Lin, Chinese University of Hong Kong (China)

Huili Gong, Capital Normal University (China)

Jiaguo Qi, University of Michigan (USA)

Jiancheng Shi, University of California at Santa Barbara (USA)

Jianya Gong, Wuhan University (China)

Jinfei Wang, University of Western Ontario (Canada)

Le Wang, Texas State University (USA)

Li Li, National Center for Fundamental Geographic Information China (China)

Ling Bian, State University of New York at Buffalo (USA)

Liqiu Meng, Technical University of Munich (Germany)

Lun Wu, Beijing University (China)

Mei-Po Kuan, Ohio State University (USA)

Michael Leitner, Louisiana State University (USA)

Min Liu, East China Normal University (China)

Ming-Hsiang (Ming) Tsou, San Diego State University (USA)

Mitsuru Sato, Pasco Corporation (Japan)

Peng Gong, University of California, Berkeley (USA), Nanjing University (China), and Institute of Remote Sensing Application, Chinese Academy of Sciences (China)

Peter Shih, National Chiao-Tung University (China)

Qiming Zhou, Hong Kong Baptist University (China)

Qingwen Qi, Institute of Geographical Science and Resources Research, Chinese Academy of Sciences (China)

Robert Weibel, University of Zurich (Switzerland) 
Shunlin Liang, University of Maryland, College Park (USA)

Shuming Bao, University of Michigan (USA)

Vicent Tao, Microsoft Corporation (USA)

Wenzhong Shi, Hong Kong Polytechnic University (China)

Xincai Wu, China University of Geosciences (China)

Xinchang Zhang, Sun Yat-sen University (China)

Xinming Tang, Chinese Academy of Surveying and Mapping (China)

Xuezhi Feng, Nanjing University (China)

Yaolin Liu, Wuhan University (China)

Yifang Ban, Royal Institute of Technology (Sweden)

Yingjie Wang, Institute of Geographical Science and Resources Research, Chinese Academy of Sciences (China)

Yong Xue, Institute of Remote Sensing Applications, Chinese Academy of Sciences (China)

Yongjiu Dai, Beijing Normal University (China)

Yongwei Sheng, University of California at Los Angeles (USA)

Yongyuan Yin, University of British Columbia (Canada)

Zhanqing Li, University of Maryland, College Park (USA)

Zhaoliang Li, Louis Pasture University (France)

Zhaoliang Shi, Jiangsu Provincial Bureau of Surveying and Mapping (China)

Zhilin Li, Hong Kong Polytechnic University (China)

\section{Local Organizing Committee}

Manchun Li, Chair, Nanjing University (China)

Weimin Ju, Chair, Nanjing University (China)

\section{Members}

Nan Jiang, Nanjing Institute of geography and Limnology, Chinese Academy of Sciences (China)

Yuexin Gong, Jiangsu Provincial Bureau of Surveying and Mapping (China)

Guoan Tang, Nanjing Normal University (China)

Xianrong Ding, Hohai University (China)

Xianhua Cai, Southeast University (China)

Xinfa Qiu, Nanjing University of Information Science \& Technology (China)

Qingjiu Tian, Nanjing University (China)

Hong Jiang, Nanjing University (China)

Shuhe Zhao, Nanjing University (China)

Jiechen Wang, Nanjing University (China) 


\section{Conference Secretariat}

Shuhe Zhao, Nanjing University (China)

Yan Li, Nanjing University (China)

Yingxia Pu, Nanjing University (China)

Qin Wang, Nanjing University (China)

Bo Zhao, Nanjing University (China)

Mei Zhang, Nanjing University (China) 


\section{Introduction}

We are pleased to present the Proceedings of the $15^{\text {th }}$ International Conference on Geoinformatics in 2007 (Geoinformatics 2007).

Since its inception in 1992, The International Association of Chinese Professionals in Geographic Information Sciences (CPGIS) has sponsored a series of International Conferences on Geoinformatics, which has enhanced academic exchange and fostered friendship and collaboration among professionals and practitioners worldwide. After successful conventions of Geoinformatics 2006 in Wuhan, China, and Geoinformatics 2005 in Toronto, Canada, Geoinformatics 2007 in Nanjing, China, this year was also highly successful. It was organized by the Department of Geographic Information Science and International Institute of Earth System Science at Nanjing University.

The conference this year was also part of the celebrations of the 50th anniversary of the cartography specialization at Nanjing University and the 15th anniversary of CPGIS. It covers a wide range of topics in theories, techniques and applications of geoinformatics, as well as new philosophical views on the future development of this discipline. Over 500 participants from more than 10 countries and regions made the Geoinformatics 2007 an exciting event.

The conference theme of Geoinformatics 2007 is "Cartography, Spatial Analysis and Visualization for Harmonious Society", which emphasizes the roles of geospatial information sciences in promoting the harmony in societies through informed land use decision making, effective visualization and analysis of spatial information in various sectors of a society, and developing new tools for integrated assessments involving multiple spatial information sources for various stakeholders, etc. This year, we received 805 abstracts, accepted 605 abstracts, and accepted 454 full papers for publication after a peer-review process. In total, 215 oral and 294 poster presentations were delivered in the conference. Through these presentations and various forums, the participants showcased their recent achievements and exchanged scientific ideas and technical skills in the field of geospatial information science. On behalf of the conference technical and local organizing committees, I would like to thank all participants in the conference and contributors to these proceedings. Your support made this year's conference a highly successful and memorable event. We sincerely hope that this momentum will continue into the future, and we count on your continued support.

Jingming Chen 